\title{
New Pyrone and Quinoline Alkaloid from Almeidea rubra and their Trypanocidal Activity
}

\author{
Alessandra R. P. Ambrozin ${ }^{a}$, Jair Mafezoli ${ }^{\#, a}$, Paulo C. Vieira ${ }^{*, a}$, João B. Fernandes ${ }^{a}$, \\ M. Fátima das G. F. da Silva ${ }^{a}$, Javier A. Ellena ${ }^{b}$ and Sérgio de Albuquerque ${ }^{c}$ \\ ${ }^{a}$ Departamento de Química, Universidade Federal de São Carlos, Rod. Washington Luiz, km 235, \\ CP 676, 13565-905 São Carlos - SP, Brazil \\ ${ }^{b}$ Instituto de Física de São Carlos, Universidade de São Paulo, Av. Trabalhador São Carlense, 400, \\ 13560-970 São Carlos - SP, Brazil \\ ${ }^{c}$ Departamento de Análises Clínicas, Toxicológicas, Bromatológicas, Faculdade de Ciências Farmacêuticas de \\ Ribeirão Preto, Universidade de São Paulo, Av. do Café, 14040-903 Ribeirão Preto - SP, Brazil
}

\begin{abstract}
O estudo da fração acetato de etila do extrato metanólico das folhas de Almeidea rubra A. St.Hil. (Rutaceae) permitiu o isolamento de duas substâncias inéditas: 4-metoxi-6-[2-(metilamino)fenil]$2 \mathrm{H}$-piran-2-ona e acetato de rel-(7R,8R)-8-[(E)-3-hidroxi-3-metil-1-butenil]-4,8-dimetoxi-5,6,7,8tetraidrofuro[2,3- $b$ ] quinolin-7-ila; e dos alcalóides arborinina, $N$-metil-1-hidroxi-3-metoxiacridona, esquimianina, cocusagina, isodutaduprina, isoesquimianina e isococusagina. Através da análise dos dados espectroscópicos foram estabelecidas as estruturas químicas das substâncias isoladas sendo que para os alcalóides inéditos tais dados são descritos pela primeira vez. Além disso, os ensaios bilógicos sobre as formas tripomastigotas do Trypanosoma cruzi das substâncias isoladas mostraram que elas possuem atividade tripanocida moderada.
\end{abstract}

The investigation of the ethyl acetate fraction of methanol extract from leaves of Almeidea rubra A. St.-Hil. (Rutaceae) afforded two new compounds 4-methoxy-6-[2-(methylamino)phenyl]-2Hpyran-2-one and rel-(7R,8R)-8-[(E)-3-hydroxy-3-methyl-1-butenyl]-4,8-dimethoxy-5,6,7,8tetrahydrofuro[2,3- $b$ ]quinoline-7-yl acetate, along with the known compounds arborinine, $N$-methyl1-hydroxy-3-methoxyacridone, skimmianine, kokusagine, isodutaduprine, isoskimmianine, and isokokusagine. Their structures were established based on their spectral data, and for the new compounds these data are described herein. Additionally, these compounds were assayed on the tripomastigote forms of Trypanosoma cruzi showing moderate trypanocidal activity.

Keywords: Almeidea rubra, Rutaceae, alkaloids, trypanocidal activity

\section{Introduction}

The genus Almeidea belongs to Rutaceae family and is widely distributed in Brazil. Data about the secondary metabolites of this genus are available. From Almeidea guyanensis was isolated $C$-arabinosyl flavones, 2- and 4quinolones, and flavone $C$-glycosides. ${ }^{1}$ We have previously reported the isolation of triterpenoids, acridone, 2-quinolone, and furoquinoline alkaloids, and a new tetrahydrofuroquinoline alkaloid from A. coeruela and $A$. rubra $^{2}$ besides steroids, one sesquiterpene, one cromone, and one flavone. ${ }^{3}$

* e-mail: paulo@dq.ufscar.br

\#Present address: UNIFOR - CCS - Curso de Farmácia, Av. Washington Soares, 1321, CP 1258, 60811-341 Fortaleza- CE.
Chagas' disease (American Trypanosomiasis) is caused by the flagellate protozoan Trypanosoma cruzi, affecting more than 18 million people in Latin America. ${ }^{4}$ Its treatment is still a challenge and new less toxic and more effective drugs are necessary.

As a part of our search for new trypanocidal compounds and our studies on the chemistry of Rutaceae, a new specimen of Almeidea rubra A. St.-Hil. was investigated. Thus, here we report the isolation, identification and characterization of two new substances (1 and $\mathbf{2 a}$ ) and seven known compounds (3-9) from methanol extract of leaves of this plant, in addition to their trypanocidal activities.

\section{Results and Discussion}

The investigation of the ethyl acetate fraction of 
methanol extract from leaves of $A$. rubra afforded two new compounds (1 and $\mathbf{2 a}$ ) and known compounds (Figure 1) arborinine (3), $\mathrm{N}$-methyl-1-hydroxy-3-methoxyacridone (4), ${ }^{5}$ skimmianine (5), ${ }^{6}$ kokusagine $(6),{ }^{7}$ isodutaduprine (7), ${ }^{8}$ isoskimmianine (8), and isokokusagine (9), which were identified through comparison of their NMR spectral data with the literature.
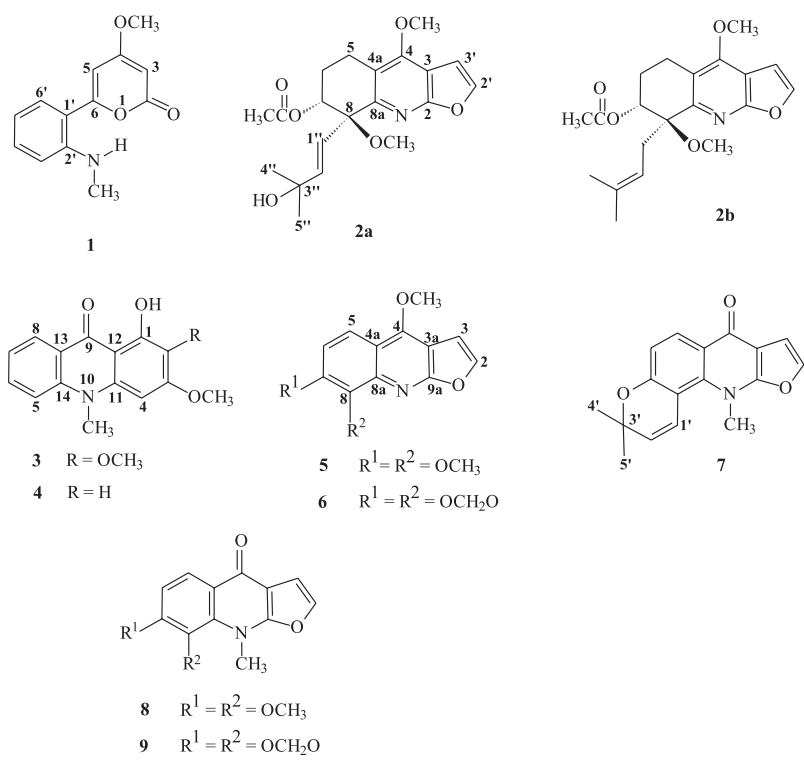

Figure 1. Compounds isolated from Almeidea rubra.

Compound $\mathbf{1}$ was isolated as a yellow powder and its structure was determined by analysis of NMR and LRMS.

The ${ }^{1} \mathrm{H}$ NMR spectrum of $\mathbf{1}$ showed aromatic protons at $\delta 7.33(2 \mathrm{H}, \mathrm{m})$, and $6.70(2 \mathrm{H}, \mathrm{m})$, assigned to H-4', H-6', and H-3', H5', respectively. Two olefinic protons (H-3 and H-5) appeared at $\delta 5.49$, and $6.23(\mathrm{~d}, J 2.2 \mathrm{~Hz})$ assigned to an 2pyrone by comparison with a styryl-2-pyrone described by Pizzolatti et al., ${ }^{9}$ besides broad $\mathrm{N}-\mathrm{H}$ and $\mathrm{N}-\mathrm{CH}_{3}$ signals at $\delta$ 5.36, and 2.87. Furthermore, a singlet at $\delta 3.85(3 \mathrm{H})$ revealed the presence of the methoxyl group in the molecule.
The ${ }^{13} \mathrm{C}$ NMR spectrum of $\mathbf{1}$ showed 13 carbons, distinguished as 5 quaternaries $(\delta 171.7,164.0,162.8$, $147.6,116.0), 4$ aromatics $(\delta 132.3,129.2,116.4,111.2)$, 2 ofelinics $(\delta 100.1,87.3), 1$ methoxyl $(\delta 55.9)$, and $1 N$ methyl carbon $(\delta 30.4)$. The analysis of ${ }^{13} \mathrm{C} \mathrm{NMR}$ and HSQC spectrum allowed us to attribute undoubtedly all chemical shifts to methyl, vinyl, and aromatic carbons/ hydrogens of $\mathbf{1}$ (Table 1 ).

The assignments of quaternary carbons were possible from observed correlations in the HMBC spectrum. The chemical shift of C-2' was deduced from ${ }^{3} J$ correlation between $\mathrm{N}-\mathrm{CH}_{3}$ hydrogens $(\delta 2.87)$ and one carbon at $\delta$ 147.6. C-4 ( $\delta$ 171.7) was assigned through ${ }^{3} J$ correlation between the lowerfield carbon and methoxyl hydrogens $(\delta$ 3.85). Furthermore, C-6 ( $\delta$ 162.8) and C-1' $(\delta$ 116.0) were determined through ${ }^{2} J-{ }^{3} J$ correlation to H-5 ( $\left.\delta 6.23\right)$. Finally, through the ${ }^{2} J$ correlation between H-3 ( $\left.\delta 5.49\right)$ and a carbonyl carbon at $\delta 164.0$ was attributed C-2.

All these results allowed us to propose the structure 4methoxy-6-[2-(methylamino)phenyl]-2 $H$-pyran-2-one for compound $\mathbf{1}$, which is described for the first time in the literature and represents a new class of compounds formed by the reaction of anthranilic acid and two acetyl/malonylCoA units.

Single crystal X-ray diffraction established undoubtedly the structure of $\mathbf{1}$ as a derivative of anthranilic acid (Figure 2).

The crystal structure of compound $\mathbf{1}$ shows the presence of two independent molecules per asymmetric unit (Figure 2 ). The main conformational difference between both independent molecules is centered in the dihedral angle between the least square planes that pass through the aromatic rings in each molecule. The value of this angle in molecule 1 is $33.58(8)^{\circ}$ and in molecule 2 is $34.79(8)^{\circ}$. The crystal structure also shows the presence of one intramolecular interaction in each molecule. These interactions are slightly different due to the conformation

Table 1. NMR spectral data $\left(\mathrm{CDCl}_{3}, 9.8 \mathrm{~T}\right)$ of substance $\mathbf{1}$ isolated from Almeidea rubra

\begin{tabular}{|c|c|c|c|c|}
\hline \multirow[b]{2}{*}{ Carbon } & \multicolumn{2}{|c|}{ HSQC } & \multicolumn{2}{|c|}{ HMBC } \\
\hline & $\delta_{\mathrm{C}}$ & $\delta_{\mathrm{H}}\left({ }^{1} J_{\mathrm{C}-\mathrm{H}}\right)$ & ${ }^{2} J_{\mathrm{C}-\mathrm{H}}$ & ${ }^{3} J_{\mathrm{C}-\mathrm{H}}$ \\
\hline 2 & 164.0 & & & \\
\hline 3 & 87.3 & $5.49 \mathrm{~d}(J 2.2 \mathrm{~Hz})$ & $171.7,164.0$ & 100.1 \\
\hline 4 & 171.7 & & & \\
\hline 5 & 100.1 & $6.23 \mathrm{~d}(J 2.2 \mathrm{~Hz})$ & $171.7,162.8$ & $116.0,87.3$ \\
\hline 6 & 162.8 & & & \\
\hline $1^{\prime}$ & 116.0 & & & \\
\hline 2 ' & 147.6 & & & \\
\hline $3^{\prime}$ and $5^{\prime}$ & $116.4,111.2$ & $6.70 \mathrm{~m}$ & $147.6,132.3,129.2$ & 116.0 \\
\hline 4' and 6' & $132.3,129.2$ & $7.33 \mathrm{~m}$ & & $162.8,147.6$ \\
\hline $4-\mathrm{OCH}_{3}$ & 55.9 & $3.85 \mathrm{~s}$ & & 171.7 \\
\hline $2^{\prime}-\mathrm{NCH}_{3}^{3}$ & 30.4 & $2.87 \mathrm{~s}$ & & 147.6 \\
\hline $2^{\prime}-N \underline{\mathrm{H}}$ & - & 5.36 br s & & \\
\hline
\end{tabular}




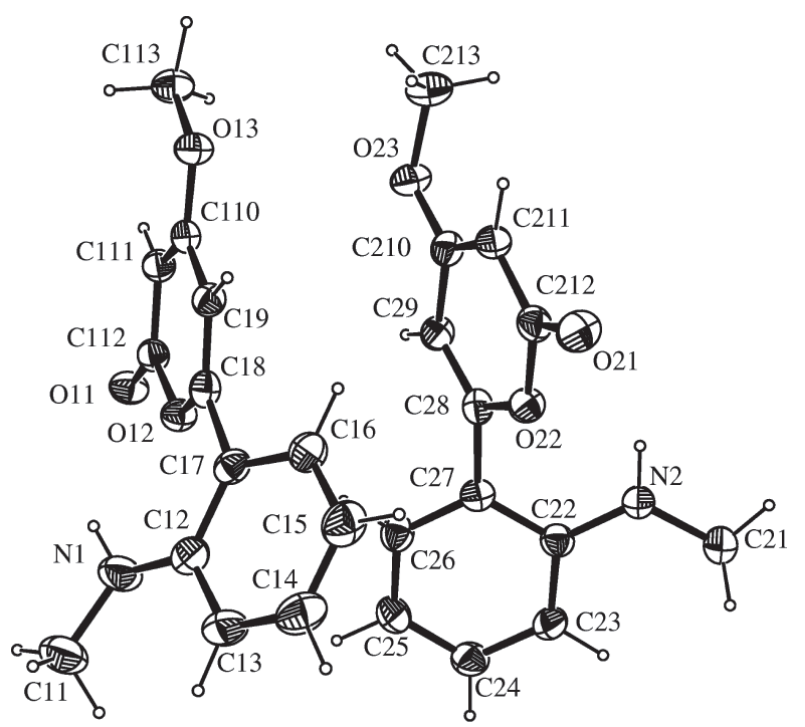

Figure 2. ORTEP-3 diagram of compound 1.

changes. The analyses of the crystal packing show the presence of four intermolecular interactions of the type C$\mathrm{H} . . . \mathrm{O}$ that give rise to the formation of chains along the (101) direction. These chains are connected with the chain just above and below it through three intermolecular interactions of the $\mathrm{N}-\mathrm{H} . . . \mathrm{O}$ type.

The quinoline and acridine alkaloids, which are widely distributed in Rutaceae, arise from combination of anthranilic acid and acetate/malonate. ${ }^{10}$ In these cases, the ciclization takes place by nucleophilic attack of nitrogen atom to the carboxyl carbon. However, compound $\mathbf{1}$ should be formed by the nucleophilic attack of the oxygen atom to the carboxyl carbon, giving rise an $\alpha$-pyrone.
We have previously reported the isolation of the new tetrahydrofuroquinoline alkaloid $\mathbf{2 b}$ (Figure 1) from $A$. coerulea. ${ }^{2}$ Reinvestigation of $A$. rubra afforded an alkaloid 2a whose spectral data seem to be very similar to those of 2b. This alkaloid was isolated as a white powder and identified by NMR and LRMS. The molecular formula $\mathrm{C}_{20} \mathrm{H}_{25} \mathrm{NO}_{6}$ of $\mathbf{2 a}$ was defined by elemental analysis.

In the ${ }^{1} \mathrm{H}$ NMR spectrum of 2a were observed a pair of doublets $(J 2.6 \mathrm{~Hz})$ at $\delta 7.58$ and 6.97 , and a singlet at $\delta$ 4.30 , which indicate that $2 \mathrm{a}$ was a tetrahydrofuroquinoline alkaloid. The signals at $\delta 2.78,2.20$, and 2.01, assigned to $\mathrm{H}-5$, and $\mathrm{H}-6$, respectively, confirmed that $\mathbf{2 a}$ had a reduced furoquinoline ring.

${ }^{1} \mathrm{H}$ NMR spectrum of 2a also showed two singlets at $\delta$ 3.14 , and 2.03, and a group of signals at $\delta 6.06(\mathrm{~d}, J 16.1$ $\mathrm{Hz}), 5.69(\mathrm{~d}, J 16.1 \mathrm{~Hz}), 1.34(\mathrm{~s})$, and $1.31(\mathrm{~s})$, which indicated the presence of the 3-hydroxy-2-isopentenyl substituent. Through the spectral data comparison, it was established that $\mathbf{2 a}$ distinguished from $\mathbf{2} \mathbf{b}$ by the presence of 3-hydroxy-2-isopentenyl substituent instead of $\gamma, \gamma$-dimethylallyl moiety.

Analysis of HSQC correlations and literature data ${ }^{2}$ allowed us to attribute undoubtedly chemical shifts to methyl, methylene, vinyl, furanyl hydrogen/carbon of $\mathbf{2 a}$ (Table 2).

The assignments of quaternary carbons of $\mathbf{2 a}$ were made from observed correlations in the HMBC spectrum. The chemical shift of C-4 was deduced from ${ }^{3} J$ correlation between methoxyl hydrogens at C-4 ( $\delta$ 4.30) and one carbon at $\delta$ 158.2. The correlation of the other methoxyl hydrogens $(\delta 3.14)$ and one carbon at $\delta 79.7$ determined

Table 2. NMR spectral data $\left(\mathrm{CDCl}_{3}, 9.8 \mathrm{~T}\right)$ of alkaloid 2a isolated from Almeidea rubra

\begin{tabular}{|c|c|c|c|c|}
\hline \multirow[b]{2}{*}{ Carbon } & \multicolumn{2}{|c|}{ HSQC } & \multicolumn{2}{|c|}{ НMBC } \\
\hline & $\delta_{\mathrm{C}}$ & $\delta_{\mathrm{H}}\left({ }^{1} J_{\mathrm{C}-\mathrm{H}}\right)$ & ${ }^{2} J_{\mathrm{C}-\mathrm{H}}$ & ${ }^{3} J_{\mathrm{C}-\mathrm{H}}$ \\
\hline 2 & 162.7 & & & \\
\hline 3 & 105.2 & & & \\
\hline 4 & 158.2 & & & \\
\hline $4 a$ & 117.6 & & & \\
\hline 5 & 19.5 & $2.78 \mathrm{~m}$ & $117.6,23.5$ & $158.2,150.0,72.6$ \\
\hline 6 & 23.5 & $2.20,2.01 \mathrm{~m}$ & $72.6,19.5$ & $117.6,79.7$ \\
\hline 7 & 72.6 & $5.43 \mathrm{dd}(J 8.5,2.9 \mathrm{~Hz})$ & 79.7 & $170.3,126.9,19.5$ \\
\hline 8 & 79.7 & & & \\
\hline $8 \mathrm{a}$ & 150.0 & & & \\
\hline $2^{\prime}$ & 142.9 & $7.58 \mathrm{~d}(J 2.6 \mathrm{~Hz})$ & & $162.7,105.2$ \\
\hline $3^{\prime}$ & 104.6 & $6.97 \mathrm{~d}(J 2.6 \mathrm{~Hz})$ & $142.9,105.2$ & 162.7 \\
\hline $1 ”$ & 126.9 & $6.06 \mathrm{~d}(J 16.1 \mathrm{~Hz})$ & & 70.8 \\
\hline $2 "$ & 141.1 & $5.69 \mathrm{~d}(J 16.1 \mathrm{~Hz})$ & 70.8 & $79.7,29.6,29.5$ \\
\hline $3 "$ & 70.8 & & & \\
\hline $4 "$ and $5 "$ & $29.6,29.5$ & $1.34,1.31 \mathrm{~s}$ & 70.8 & 141.1 \\
\hline $4-\mathrm{OCH}_{3}$ & 58.5 & $4.30 \mathrm{~s}$ & & 158.2 \\
\hline $8-\mathrm{OCH}_{3}$ & 51.3 & $3.14 \mathrm{~s}$ & & 79.7 \\
\hline$-\mathrm{OOCCH}_{3}$ & 170.3 & & & \\
\hline$-\mathrm{OOC} \underline{\mathrm{H}}_{3}$ & 21.2 & $2.03 \mathrm{~s}$ & & 170.3 \\
\hline
\end{tabular}


C-8. C-4a was assigned through correlation between the carbon at $\delta 117.6$ and H-5, and H-6 $(\delta 2.78$, and 2.01). H-5 also correlated to C-8a $(\delta$ 150.0). Furthermore, methyl hydrogens at $\delta 1.34$, and 1.31 , correlated with an oxygenated carbon at $\delta 70.8$, establishing C-3". Finally, the correlation between furanyl hydrogens $(\delta 7.58$, and 6.97) and quaternary carbons at $\delta 162.7$, and 105.2 determined $\mathrm{C}-2$, and $\mathrm{C}-3$, respectively.

The close similarity between the chemical shifts observed for carbons of reduced furoquinoline ring when compared with the model compound 7-O-acetylhaplophyllidine $(\mathbf{2} \mathbf{b})^{2}$ led us to suggest a trans relationship between the 7-acetoxy and 8-methoxy groups. Alkaloid 2a, rel-(7R,8R)-8-[(E)-3-hydroxy-3-methyl-1-butenyl]4,8-dimethoxy-5,6,7,8-tetrahydrofuro [2,3-b]quinoline-7$\mathrm{yl}$ acetate, is described for the first time in the literature, and the occurrence of tetrahydrofuroquinoline alkaloid such as $\mathbf{2 a}$ and $\mathbf{2 b}$ seems to be restricted to the genera Almeidea and Haplophyllum of Rutaceae family.,11

In order to improve the therapy of Chagas disease, we have been studying species of the order Rutales (Rutaceae, Meliaceae, Simaroubaceae, Burseraceae, and Cneoraceae) aiming to isolate hit compounds that could be used in the development of new antichagasic drugs.

Compounds described in this paper were isolated from an active fraction of A. rubra (62.9\% lysis - percent reduction of the parasite number) on the tripomastigote forms of T. cruzi. ${ }^{12}$ Their in vitro trypanocidal actions are shown on Table 3. Three of them (7-9) could not be assayed due to their instability.

Table 3. Trypanocidal activity of compounds isolated from Almeidea rubra

\begin{tabular}{|c|c|c|c|c|}
\hline \multirow[t]{2}{*}{ Compound } & \multicolumn{3}{|c|}{ Concentration $(\mu \mathrm{g} / \mathrm{mL}) \times$ Lysis $\%$} & \multirow{2}{*}{$\begin{array}{c}\mathrm{IC}_{50} \\
(\mathrm{mmol} / \mathrm{L})\end{array}$} \\
\hline & 500 & 250 & 100 & \\
\hline 1 & 74.10 & 45.08 & 27.23 & 1.271 \\
\hline $2 \mathbf{a}$ & 58.93 & 44.20 & 28.12 & 0.977 \\
\hline 3 & 57.99 & 42.39 & 24.00 & 1.231 \\
\hline 4 & 45.60 & 43.20 & 31.20 & 2.600 \\
\hline 5 & 65.17 & 30.35 & 25.44 & 1.455 \\
\hline 6 & 58.38 & 57.13 & 46.58 & 0.5596 \\
\hline
\end{tabular}

The results showed that all of compounds had moderate trypanocidal actions and kokusagine (6) was the most active one. Probably, they are responsible by the activity of the A. rubra fraction. ${ }^{12}$ However, they could not be considered good prototype for the development of new antichagasic drugs, mainly when their activities are compared with crystal violet and some lignans also isolated from other Rutaceae. ${ }^{13}$

\section{Experimental}

\section{General experimental procedures}

The ${ }^{1} \mathrm{H}$ NMR, ${ }^{13} \mathrm{C}$ NMR and 2D correlation spectra were obtained in $\mathrm{CDCl}_{3}$ using either Bruker DRX-200 and ARX400 NMR spectrometers, and using tetramethylsilane (TMS) as internal standard.

Low resolution EIMS were recorded on GC-17A, GCMS-QP5000 Shimadzu.

\section{Plant material}

The leaves of Almeidea rubra A. St.-Hil. were collected in May 2000 in Espírito Santo State, southeast of Brazil. The plant material was identified by Dr. José Rubens Pirani from the Department of Botany, University of São Paulo (Brazil) and the voucher herbarium specimen (Pirani et al. 4746) was deposited at the Herbarium of that Department.

\section{Extraction and isolation}

Dried leaves (313.5 g) were extracted first with hexane and then with $\mathrm{MeOH}$ at room temp. Part of the methanol extract (15.9 g) was submitted to VLC on silica gel 60 (70230 mesh) using a hexane- $\mathrm{CH}_{2} \mathrm{Cl}_{2}$-EtOAc- $\mathrm{MeOH}$ gradient, to yield the corresponding fractions (ALFMH, ALFMD, ALFMA, ALFMM). The fraction ALFMA (3.3208 g) was submitted to column chromatography over silica (silica gel 230-400 mesh, 410 x $43 \mathrm{~mm}$ i.d., stepwise with a hexane-EtOAc-MeOH gradient) to give eleven fractions.

The second fraction (ALFMA2;0.6302 g) was chromatographed on silica gel column (230-400 mesh, $358 \times 31 \mathrm{~mm}$ i.d.) and eluted with solvents of increasing polarity (hexane:AcOEt $8: 2 \rightarrow \mathrm{MeOH}$ ) to afford ten fractions. Through column chromatography over sephadex LH-20 (492 x 32 mm i.d., eluted with $\mathrm{CH}_{2} \mathrm{Cl}_{2}: \mathrm{MeOH}$ 1:1) from the fraction five (ALFMA2,5; $103.6 \mathrm{mg}$ ) was obtained four fractions. Then, the second fraction (ALFMA2,5,2; $68.0 \mathrm{mg}$ ) was subjected to column chromatography over silica gel (230-400 mesh, 394 x $32 \mathrm{~mm}$ i.d., stepwise with $\mathrm{a} \mathrm{CH}_{2} \mathrm{Cl}_{2} \rightarrow \mathrm{MeOH}$ gradient) to give four fractions. The third fraction (ALFMA2,5,2,3;36.0 mg) was chromatographed on sephadex LH-20 column ( $492 \times 32 \mathrm{~mm}$ i.d.) and eluted with $\mathrm{CH}_{2} \mathrm{Cl}_{2}: \mathrm{MeOH}$ (1:1) to afford six fractions. Through column chromatography over silica gel (230-400 mesh, 394 x 32 mm i.d., stepwise with a $\mathrm{CH}_{2} \mathrm{Cl}_{2} \rightarrow \mathrm{MeOH}$ gradient) of the fraction five (ALFMA2,5,2,3,5;14.3 mg) was isolated the alkaloid 2a (2.6 mg).

Fraction four (ALFMA4; $178.1 \mathrm{mg}$ ) was chromatographed on sephadex LH-20 column (492 x 32 mm i.d.) 
and eluted with $\mathrm{MeOH}$ to afford five fractions. Through column chromatography over sephadex LH-20 (492 x 32 mm i.d., eluted with $\left.\mathrm{CH}_{2} \mathrm{Cl}_{2}: \mathrm{MeOH} 1: 1\right)$ of the third fraction (ALFMA4,3; $59.9 \mathrm{mg}$ ) was obtained the alkaloid 5 (ALFMA4,3,7; $2.5 \mathrm{mg}$ ) and eight fractions. Then, the fourth fraction (ALFMA4,3,4; $2.3 \mathrm{mg}$ ) was subjected to column chromatography over sephadex LH-20 (332 x 25 mm i.d., eluted with $\mathrm{CH}_{2} \mathrm{Cl}_{2}: \mathrm{MeOH} \mathrm{1:1)}$ to give three fractions. Further purification of the fraction two (ALFMA4,3,4,2; $2.0 \mathrm{mg}$ ) on preparative planar silica plate with hexane:EtOAc (8:2) afforded alkaloid 6 (1.6 mg). Through column chromatography over sephadex LH-20 (492 x 32 mm i.d., eluted with $\left.\mathrm{CH}_{2} \mathrm{Cl}_{2}: \mathrm{MeOH}\right)$ of the fraction five (ALFMA4,3,5;21.5 mg) was isolated the compound 1 (14.7 $\mathrm{mg})$.

The alkaloids arborinine (3) (43.2 $\mathrm{mg})$, isodutaduprine (7) $(25.6 \mathrm{mg})$, and isoskimmianine $(\mathbf{8})(28.8 \mathrm{mg})$ were crystallized in $\mathrm{MeOH}$ from fraction six (ALFMA6; 104.5 $\mathrm{mg}$ ), seven (ALFMA7; $317.3 \mathrm{mg}$ ) and nine (ALFMA9; $120.5 \mathrm{mg}$ ), respectively.

The other alkaloid isokokusagine (9) (32.1 mg) was purified on sephadex LH-20 (492 x 32 mm i.d., eluted with $\mathrm{MeOH}$ ) from fraction eight (ALFMA8; $90.3 \mathrm{mg}$ ), and the alkaloid $4(3.2 \mathrm{mg})$ was obtained from fraction three (148.8 mg).

4-methoxy-6-[2-(methylamino)phenyl]-2H-pyran-2-one (1)

Yellow powder; elemental analysis (Found: C, 68.0432; $\mathrm{H}, 5.565904 ; \mathrm{N}, 6.11885$. Calc. for $\mathrm{C}_{13} \mathrm{H}_{13} \mathrm{NO}_{3}$ : C, 67.53; $\mathrm{H}, 5.63 ; \mathrm{N}, 6.06 \%)$; UV $\lambda_{\text {max }} / \mathrm{nm}\left(\mathrm{CH}_{2} \mathrm{Cl}_{2}\right): 240,250,283$, $303,332,371$; IR $v_{\max } / \mathrm{cm}^{-1}: 2920,2855,1719,1630,1557$, 1401, 1010 (film); ${ }^{1} \mathrm{H} \mathrm{NMR}\left(\mathrm{CDCl}_{3}, 400 \mathrm{MHz}\right)$ : Table 1; ${ }^{13} \mathrm{C} \mathrm{NMR}\left(\mathrm{CDCl}_{3}, 100 \mathrm{MHz}\right)$ : Table 1; EIMS m/z: 231, 200, 199, 104, 77 .

Rel-(7R,8R)-8-[(E)-3-hydroxy-3-methyl-1-butenyl]-4,8dimethoxy-5,6,7,8-tetrahydrofuro[2,3-b]quinoline-7-yl acetate (2a)

White powder; $[\alpha]_{\mathrm{D}}{ }^{25}=-8.7^{\circ}\left(c 0.15, \mathrm{CH}_{2} \mathrm{Cl}_{2}\right)$; elemental analysis (Found: C, 61.76958; H, 7.457999; N, 4.316954. Calc. for $\mathrm{C}_{20} \mathrm{H}_{25} \mathrm{NO}_{6}: \mathrm{C}, 64.00 ; \mathrm{H}, 6.67 ; \mathrm{N}$, $3.73 \%)$; IR $v_{\max } / \mathrm{cm}^{-1}: 2922,2855,1741,1579,1371,1327$,

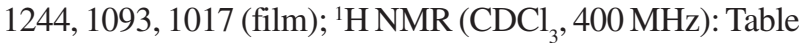
$2 ;{ }^{13} \mathrm{C} \mathrm{NMR}\left(\mathrm{CDCl}_{3}, 100 \mathrm{MHz}\right)$ : Table 2; EIMS m/z: 226, 266, 326.

Single crystal $X$-ray analysis

Low temperature X-ray diffraction data collection was performed at 120(2) K, on an Enraf-Nonius Kappa-CCD diffractometer equipped with an Oxford Cryosystem liquid $\mathrm{N}_{2}$ device, using graphite-monochromated $\mathrm{MoK} \alpha$ radiation $(0.71073 \AA)$. Data were collected up to $50^{\circ}$ in $2 \theta$, with a redundancy of 4 . The final unit cell parameters were based on all reflections. Data collections were made using the COLLECT program; ${ }^{14}$ integration and scaling of the reflections were performed with the HKL Denzo-Scalepack system of programs. ${ }^{15}$ No absorption corrections were applied.

The structure was solved by direct methods with SHELXS-97. ${ }^{16}$ The model was refined by full-matrix least squares on $\mathrm{F}^{2}$ with SHELXL-97. ${ }^{17}$ All the hydrogen atoms were set isotropic and freely refined. The programs SHELXL-97, ${ }^{17}$ and ORTEP-3 ${ }^{18}$ were used within WinGX ${ }^{19}$ to prepare materials for publication. Atomic coordinates, bond lengths and angles, and thermal parameters have been deposited at the Cambridge Crystallographic Data Centre.

The supplementary crystallographic data have been sent in electronic format to the Cambridge Crystallographic Data Centre, as CIF file No. CCDC 242119. These can be obtained obtained free of charge by contacting the CCDC (12 Union Road, Cambridge CB2 1EZ, UK; fax: +44 1223 336033; www.ccdc.cam.ac.uk/conts/retrieving.html; deposit@ccdc.cam.ac.uk).

\section{Trypanocidal activity in vitro}

As described by Ambrozin et al. ${ }^{12}$ the bioassays were carried out using blood of infected Swiss albino mice, which was collected by cardiac puncture at the peak of parasitemic infection $\left(7^{\text {th }}\right.$ day of infection for Y strain of $T$. cruzi). The infected blood was diluted with healthy mice blood to achieve a concentration of $2.10^{6}$ forms $/ \mathrm{mL}$. Solutions of the compounds were prepared by dissolving in dimethylsulfoxide (DMSO). The activities of substances were evaluated at 500, 250, and $100 \mu \mathrm{g} / \mathrm{mL}$.

The bioassays were performed in triplicate on titration microplates (96 wells) which contained $400 \mu \mathrm{L}$ mixture/ well. The plates were incubated at $4{ }^{\circ} \mathrm{C}$, and the number of parasites counted after $24 \mathrm{~h}$, following the method described by Brener. ${ }^{20}$

Infected blood with the same volume of DMSO was used as control, and gentian violet to a concentration of $250 \mu \mathrm{g} / \mathrm{mL}$ was used as positive control.

The activity is expressed as percent reduction of the parasite number (lysis) and $\mathrm{IC}_{50}$ values were calculated using the program GraphPad Prims v.3.0.

\section{Acknowledgments}

The authors are grateful to FAPESP and CNPq for the 
financial support and to Dr José Rubens Pirani for collecting and identifying the Almeidea rubra specimen.

\section{References}

1. Jay, M.; Gleye, J.; Bouillant, M.L.; Stanislas, E.; Moretti, C.; Phytochemistry 1979, 18, 184 ; Moulis, C.; Wirasutisna, K.R.; Gleye, J.; Loiseau, P.; Stanislas, E.; Moretti, C.; Phytochemistry 1983, 22, 2095; Wirasutisna, K.R.; Gleye, J.; Moulis, C.; Stanislas, E.; Moretti, C.; Phytochemistry 1986, 25, 558.

2. Santos, C.S.; Januário, A.H.; Vieira, P.C.; Fernandes, J.B.; Da Silva, M.F.G.F.; Pirani, J.R.; J. Braz. Chem. Soc. 1998, 9, 39.

3. Januário, A.H.; PhD. Thesis, Universidade Federal de São Carlos, 1995; Mafezoli, J.; Ph D. Thesis, Universidade Federal de São Carlos, 2001.

4. http://www.who.int/ctd/chagas/disease.htm, accessed in May 2004.

5. Bergenthal, D.; Mester, I.; Rósza, Zs.; Reisch, J.; Phytochemistry 1979, 18, 161.

6. Ahond, A.; Picot, F.; Potier, P.; Poupat, C.; Sévenet, T.; Phytochemistry 1978, 17, 166.

7. Yajima, T.; Kato, N.; Munakata, K.; Agric. Biol. Chem. 1977, 41, 1263.

8. Baudouin, G.; Tillequin, F.; Koch, M.; Pusset, J.; Sevenet, T.; J. Nat. Prod. 1981, 44, 546.

9. Pizzolatti, M.G.; Luciano, C.; Monache, F.D.; Phytochemistry 2000, 55, 819 .

10. Dewick, P.M.; Medicinal Natural Products: A Biosynthetic Approach, John Wiley \& Sons: England, 1997; Waterman, P.G.; Phytochemistry 1999, 27, 395.
11. Rózsa, Zs.; Rábik, M.; Szendrei, K.; Kálmán, A.; Argay, Gy.; Pelczer, I.; Aynechi, M.; Mester, I.; Reisch, J.; Phytochemistry 1986, 25, 2005.

12. Ambrozin, A.R.P.; Vieira, P.C.; Fernandes, J.B.; da Silva, M.F.G.F.; de Albuquerque, S.; Mem. Inst. Oswaldo Cruz 2004, 99, 227.

13. Bastos, J.K.; de Albuquerque, S.; Silva, M.L.A; Planta Med. 1999, 65, 541.

14. Enraf-Nonius, 1997-2000. COLLECT. Nonius BV, Delft, The Netherlands.

15. Otwinowski, Z.; Minor, W. In Methods in Enzymology; CarterJr., C.W.; Sweet, R.M.; eds., Academic Press: New York, 1997, p. $276,307$.

16. Sheldrick, G. M.; SHELXS-97; Program for Crystal Structure Resolution; University of Göttingen, Germany, 1997.

17. Sheldrick, G. M.; SHELXL-97; Program for Crystal Structures Analysis; University of Göttingen, Germany, 1997.

18. Farrugia, L.J.; J. Appl. Cryst. 1997, 30, 565.

19. Farrugia, L.J.; WinGX; An Integrate System of Windows Programs for the Solution, Refinement and Analysis of Single Crystal X-Ray Diffraction Data; University of Glasgow, 19972003.

20. Brener, Z.; Rev. Inst. Med. Trop. S. Paulo 1962, 4, 389.

Received: December 2, 2004

Published on the web: April 12, 2005

FAPESP helped in meeting the publication costs of this article. 